\title{
Using an English Novel to Improve Saudi EFL Reading Skills
}

\author{
Hammad Ali Alshammari (Corresponding Author) \\ English Department, College of Arts, Jouf University, Kingdom of Saudi Arabia \\ E-mail: ksa.usa.h@hotmail.com
}

Elsayed Abdallah Ahmed

English Department, College of Arts, Jouf University, Kingdom of Saudi Arabia

E-mail: eaahmed@ju.edu.sa

Received: April 23, 2019 Accepted: June 25, 2019 Published: July 1, 2019

doi:10.5296/elr.v5i2.14710 URL: https://doi.org/10.5296/elr.v5i2.14710

\begin{abstract}
This mixed-methods study investigated10 Saudi EFL university students' perceptions of the use of authentic literary materials in an intensive three-week reading intervention involving Charles Dickens' novel Great Expectations. Participants were equally divided into an experimental group and a control group. The study collected quantitative data from a pre-test and post-test to measure reading progress and collected qualitative data through semi-structured interviews. The results showed participants held positive attitudes about using interactive instruction with authentic literary texts, such as novels, in the Saudi EFL reading classroom. Despite this positive attitude, participants faced some challenges in their initial exposure to the experiment, mainly due to a lack of vocabulary and being unaccustomed to reading such a long text.
\end{abstract}

Keywords: Language skills, Literature, EFL, ESL, Saudi Arabia, Reading

\section{Introduction}

Learning a second language (L2) is a demanding but increasingly important process to obtain employment and facilitate effective communication around the world. Most educators and researchers have found Saudi learners of English as a foreign language (EFL) encounter great difficulty learning English in Saudi Arabia (Al-Nasser, 2015), and a large body of literature claims Saudi EFL learners have poor reading skills in particular, regardless of their academic level, which could reduce linguistic performance later in life (Al-Qahtani, 2016). 


\section{Macrothink}

Therefore, the present study investigated the underlying reasons behind these reading problems in order to find potential solutions. Most related studies examined factors that might influence L2 reading ability, such as technology or the effect of the first language (L1) on the L2 (Grabe, 2004; Koda, 2005). However, few studies have investigated Saudi EFL attitudes toward reading through the use of authentic literary materials, such as novels. Thus, the present study has explored to what extent using a novel in a Saudi EFL classroom influenced students' L2 reading ability.

In addition to providing data on how Saudi EFL learners can improve their English reading ability, this study presents a unique technique in associating language learning with literature by implementing one literary source (a novel) to teach one linguistic skill (reading). While there is limited research on improving the reading skills of Saudi EFL learners using a literary device, specifically a novel, no studies could be found that implemented Charles Dickens' Great Expectations, which was used in this study.

\section{Background}

Due to its importance in international communication, English was approved to be taught in Saudi schools in 1972 (Alamri, 2008; Al-Qahtani, 2016). The 1980 saw "a strong reawakening of interest in literature and language teaching" (Zafeiriadou, 2004). This is because literature can be a motivator during the learning process, and since "Literature is authentic ... learners are thus exposed to language that is genuine and undistorted as can be managed in the classroom context" (Collie \& Slater, 1987). Thus, it has been claimed that literature in the classroom provides language learners with more authentic material (Elliot, 1990), exposing them to "native-like competence" (Obeidat, 1997).

Although it is important to focus on a variety of language skills, one of the most crucial for university students is reading (Levine, Ferenz, \& Reves, 2000). However, Saudi EFL learners often display poor reading skills, leading to low overall reading performance (Al-Qahtani, 2016). Such difficulties could be associated with the "conscious and unconscious thinking process" required for fluent reading (Mikulecky, 2008). Furthermore, Saudi university EFL reading classes tend to follow traditional methods of teaching, where most lessons are based on a teacher-centered approach, with students given an inactive role in the learning process. Rodrigues and Ponce (2013) argued learners need to be actively involved in their learning, be able to interact with teachers, and be able to evaluate and synthesize the material.

Traditional L2 reading instruction could therefore be negatively affected by low motivation among learners with some academic materials. However, reading instructors might be able to increase learners' motivation and activate their intrinsic positive feelings toward learning through the use of literature. According to Collie and Slater (1987), teachers might use literary materials such as novels in their reading classrooms to increase students' L2 cultural background, provide authentic texts that reflect real-life situations, help learners improve their language performance, and activate their personal involvement in the text.

One of the main reasons for selecting a novel is the large number of studies that have shown positive findings from this technique (e.g., Carroli, 2008; Duff \& Maley, 1990; Khatib, Rezaei, \& Derakhshan, 2011; Langer, 1997). Using a novel as a teaching tool could help increase learners' L2 competence at different linguistic levels. This technique has been shown 
to increase EFL learners' fluency (MacGowan-Gilhooly, 1991), vocabulary (Horst, 2005), and motivation (Elley, 1991; Krashen, 1993).

\section{Research Method}

\subsection{Research Questions}

This study was guided by three research questions:

Q1: What are Saudi EFL learners' perceptions about using Great Expectations in their EFL reading classes?

Q2: To what extent does exposing Saudi EFL learners to Great Expectations help improve their overall reading performance?

Q3: What is the most important reading skill improved by this intervention?

\subsection{Participants}

This study had 10 participants equally divided into a control group and an experimental group (see Table 1). All participants were male Saudi native speakers of Arabic, 21 years old on average, with the same educational background. All were pursuing a BA in English during their fifth semester at a northern university in Saudi Arabia and had registered for a Reading II course. They were recruited based on two main criteria: having an overall GPA above 4 out of 5 and having two recommendations from their current professors.

Table 1. Overview of participants

\begin{tabular}{lllllllllll}
\hline Participant & P1 & P2 & P3 & P4 & P5 & P6 & P7 & P8 & P9 & P10 \\
& EXP & EXP & EXP & EXP & EXP & CNT & CNT & CNT & CNT & CNT \\
\hline GPA out of 5 & 4.10 & 4.06 & 4.29 & 4.01 & 4.49 & 4.28 & 4.35 & 4.08 & 4.03 & 4.53 \\
Age & 22 & 21 & 22 & 20 & 21 & 22 & 22 & 22 & 21 & 20 \\
\hline
\end{tabular}

\subsection{Instrument}

The study was divided into two main stages to reveal participant perceptions about using an English novel to improve their reading skills. First, the experimental group (Participants 1-5) were given an explicit reading intervention that included memorizing vocabulary items, strategies to read quickly, increasing overall reading comprehension, and interacting with the novel from different perspectives, such as cultural and political perspectives. The intervention took place during three weeks, three hours per school day. This study followed a qualitative approach by conducting semi-structured interviews regarding reading improvement. In addition, the study exposed all 10 participants to a three-week period of reading Great Expectations. Reading instruction included such skills as scanning, skimming, and guessing meaning from context. Their performance was analyzed based on their first and second exams for the course, taken four weeks apart, which acted as a pre-test and post-test administered before and after the intervention.

\subsection{Interview Questions}

The following questions were asked during the semi-structured interviews: 


\section{Macrothink}

1) Do you think your reading level has improved after you were exposed to Great Expectations? If so, in what way?

2) Do you think you need to read more novels? Why?

3) Do you like reading Arabic novels? Why? Which novels, if any?

4) Did you find reading Great Expectations to be interesting?

5) What did you find to be the most interesting part of Great Expectations?

6) Did you have any difficulties reading Great Expectations? If so, what were they?

7) Do you think reading Great Expectations helped you understand the cultural, social, political, and historical background and setting of the novel?

8) Do you think reading Great Expectations helped you improve your overall reading comprehension?

9) Do you think reading Great Expectations helped you improve your overall vocabulary, phrasing, and sentence structure?

10) Do you think reading Great Expectations helped you improve your reading speed and scanning?

The first seven questions sought to answer Research Question 1, Interview Question 8 sought to answer Research Question 2, and the last two interview questions shed light on the third research question.

\subsection{Procedure}

The researchers invited 18 students who met the abovementioned requirements, and 10 ultimately agreed to participate. They were divided into the experimental or control group. One week later, the experimental group was given detailed instructions for reading Great Expectations.

\section{Results}

Below, the results of participants' scores on their first and second exams for Reading II (pre-test and post-test) are presented (see Table 2), including mean and standard deviation. This is followed by the results of the experimental group's interview responses to Questions $1-10$.

Table 2. Participants' performance on Pre- and Post-Tests

\begin{tabular}{lllllllllll}
\hline Participant & P1 & P2 & P3 & P4 & P5 & P6 & P7 & P8 & P9 & P10 \\
\hline Pre-test & 73 & 81 & 87 & 74 & 79 & 75 & 82 & 91 & 84 & 69 \\
Post-test & 88 & 96 & 99 & 92 & 93 & 83 & 88 & 88 & 90 & 85 \\
Mean & 80.5 & 88.5 & 93 & 83 & 86 & 79 & 85 & 89.5 & 87 & 77 \\
SD & 10.60 & 10.60 & 8.48 & 12.72 & 9.89 & 5.65 & 4.24 & 2.12 & 4.24 & 11.31 \\
\hline
\end{tabular}

Table 2 shows the progress in Saudi EFL learners' reading ability between the first and second exams (see also Figure 1). All participants improved regardless of group. However, the standard deviation for the experiment group reflected overall higher improvement. The 
one exception wasParticipant10 in the control group, whose standard deviation demonstrated improvement close to or better than that of the experimental group.

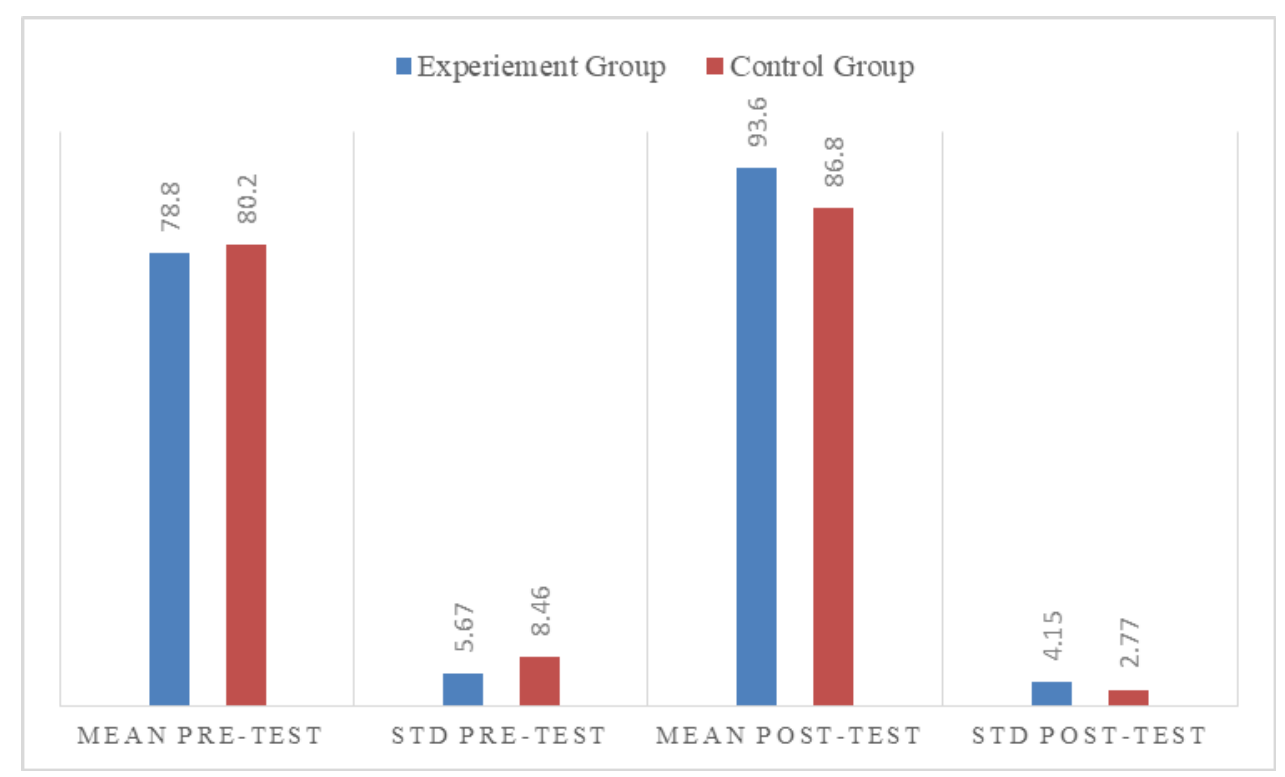

Figure 1. Overall reading progress

The following paragraphs present the qualitative data collected from interviews with the experimental group. Regarding Question 1 (Do you think your reading level has improved after you were exposed to Great Expectations? If so, in what way?), all five participants in the experimental group responded positively, mostly with short answers, such as "Yes, I do"; however, Participant 4 gave a slightly stronger response ("Yes, I strongly do") that Great Expectations had improved his reading level in a noticeable way.

Regarding Question 2 (Do you think you need to read more novels? Why?), participants gave different responses. Participants 1 and 5 insisted they would like to read more novels, and when asked why, they provided different justifications. Participant 1 stated, "I would like to read more novels because doing so will help me improve my English," while Participant 2 said, "I strongly think I need to read more novels, because I like writing short stories." The rest of the participants, however, responded with a conditional "yes" provided the novel was appropriate. For instance, Participant 2 said, "I don't think I'll read more novels unless I find the right one," and when asked what he meant by "the right one," he said, "a novel that is readable and interesting." Readable referred to the novel not being written in advanced or difficult language.

Regarding Question 3 (Do you like reading Arabic novels? Why? Which novels, if any?), the responses of Participants 1,2, 4, and 5 revealed negative feelings toward reading Arabic novels, as they said they did not like reading such novels. When those four participants were asked why, they stated they were never taught how to read Arabic novels in school. The exception was Participant 3, who said he liked reading Arabic novels. When asked what Arabic novels he had liked reading, he mentioned The Spider by Egyptian writer Mustafa Mahmoud. When asked what Saudi novels he had read, he showed little interest in them, 
saying, "Most Saudi novels don't show as much imagination or increase my cultural knowledge." He added, "How could Saudi novels provide me more cultural knowledge when I already live in that culture and understand most of it?" He added, "That isn't meant to reflect poorly on Saudi novels. I just really like learning more about other cultures."

In answer to Question 4 (Did you find reading Great Expectations to be interesting?), Participants 2 and 5 said, "It was not interesting...but it became very interesting." When asked what changed their minds about this novel, Participant 2 said, "I was really not able to understand most of it" because "I couldn't figure out the meaning of most of the vocabulary," while Participant 5 said, "It was difficult for me and uninteresting because I was not used to reading a very long piece of writing." He pointed out that he lacked experience reading Arabic novels, meaning this type of reading was a new experience for him.

Question 5(What did you find to be the most interesting part of Great Expectations?) resulted in a variety of answers. Participant 1 said, "the fight between the two criminals," Participant 2 said, "the love story," Participant 3 said, "the love story as well as the death of the person who gave Pip the money," Participant 4 said, "the blacksmith visiting Pip in London," and Participant 5 said, "stealing the meat pie Pip's sister made for Christmas."

Regarding Question 6 (Did you have any difficulties reading Great Expectations? If so, what were they?), all five participants said they experienced difficulties during their reading of Great Expectations. Participants 2-5 reported their biggest problem was an insufficient vocabulary, which prevented them from interacting with the text. Participant 1 reported his biggest difficulty was the demand of connecting all the novel's incidents to understand later events, as he said, "I need to put all the minor incidents together to have an overall understanding." He said this posed a problem because he was unfamiliar with long connected organic narratives.

In answer to Question 7 (Do you think reading Great Expectations helped you understand the cultural, social, political, and historical background and setting of the novel?), all responses were positive. For instance, Participant 3 said, "There were two primary social classes: labors and nobles or poor and rich." Participants 1, 2, and 5 said they were shocked by the British court system regarding the death penalty as well as offering lawyers to defend criminals in the early 19 th century.

Regarding Question 8 (Do you think reading Great Expectations helped you improve your overall reading comprehension?), all responses were positive and reflected a desire to read more novels that were authentic and exciting.

Regarding Question9 (Do you think reading Great Expectations helped you improve your overall vocabulary, phrasing, and sentence structure?), all participants provided similar positive responses. Participant 1, for example, claimed he learned over 100 new words, such as "file" and "sorrow," as well as phrases, such as "God bless you" and "broken heart." The other participants provided similar examples.

Regarding Question 10 (Do you think reading Great Expectations helped you improve your reading speed and scanning?), Participants 3 and 5 stated that reading novels helped them develop those skills after the three-week intervention. Participant 3 said, "Great Expectations made me expect great reading skills." Participants 1, 2, and 4 gave similar responses that they 
moved their eyes faster while reading. Participant 2 said he was practicing reading faster by recording his voice reading aloud and that "I find myself reading more quickly."

\section{Discussion and Conclusion}

There is an increasing demand for reading skills among Saudi EFL learners since reading is one of the most important language skills at the university level (Levine et al., 2000). The results of the present study shed light on Saudi EFL learners' reading difficulties and ways to improve this important skill. Based on participants' test scores and post-intervention interviews, using a novel was shown to help develop the reading comprehension of Saudi EFL learners. This strategy provided learners with greater exposure to advanced and diverse vocabulary and grammatical structures. Moreover, the experimental group showed largely positive perceptions about using a novel in language classrooms, supporting the claims of Elliot (1990) and Obeidat (1997). Based on these results, reading teachers are recommended to employ authentic material in reading instruction to motivate learners, avoid traditional methods of teaching that are less beneficial in university classrooms, and rely on methods that help students interact creatively with the text and language. In spite of these benefits, this strategy came with some challenges for Saudi EFL learners, especially in the initial stage of implementing a novel in reading classrooms, including insufficient vocabulary, lack of fast reading strategies, lack of self-confidence, and resisting unfamiliar methods of teaching and new types of texts (novels) that are not designed for the classroom.

\section{Recommendations}

Based on the findings, teachers should use implicit rather than explicit reading strategies, especially those related to literature. Reading instructors should also avoid depending entirely on academic texts, which can cause EFL learners to feel less motivated and not fully integrated in the classroom. Using a greater variety of authentic texts can help Saudi EFL learners interact more with the text and feel more confident in their learning.

Since this study focused on reading, future studies could examine the effects of employing literary materials in other relevant language skills, such as writing. Another limitation that could be addressed in future research would be to include more than one gender. Since this study only had participants at the university level, future studies could also include students from various levels, such as beginners and intermediate learners.

\section{References}

Alamri, A. M. (2008). An evaluation of the sixth grade English language (Master's thesis). Retrieved from http://faculty.ksu.edu.sa/amri/Documents/MA\%20thesis.pdf

Al-Qahtani, A. (2016). Why do Saudi EFL readers exhibit poor reading abilities? English Language and Literature Studies, 6(1), 1-15. https://doi.org/10.5539/ells.v6n1p1

Al-Nasser, A. (2015). Problems of English language acquisition in Saudi Arabia: An exploratory-cum-remedial study. Theory and Practice in Language Studies, 5(8), 1612-1619. https://doi.org/10.17507/tpls.0508.10

Carroli, P. (2008). Literature in second language education. New York, NY: Continuum.

Collie, J., \& Slater, S. (1987). Literature in the language classroom: A resource book of ideas and activities. New York, NY: Cambridge University Press. 


\section{Macrothink}

Duff, A., \& Maley, A. (1990). Literature. Oxford, UK: Oxford University Press.

Elley, W. B. (1991). Acquiring literacy in a second language: The effect of book-based programs. Language Learning, 41(3), 375-411. https://doi.org/10.1111/j.1467-1770.1991. tb00611.x

Elliot, R. (1990). Encouraging reader-response in ESL situations. ELT Journal, 44(3), 191-198. https://doi.org/10.1093/elt/44.3.191

Grabe, W. (2004). Research on teaching reading. Annual Review of Applied Linguistics, 24, 44-69. https://doi.org/10.1017/S0267190504000030

Horst, M. (2005). Learning L2 vocabulary through extensive reading: A measurement study. Canadian Modern Language Review, 61(3), 355-382. https://doi.org/10.3138/cmlr.61.3.355

Khatib, M., Rezaei, R., \& Derakhshan, A. (2011). Literature in the EFL/ESL classroom. English Language Teaching, 4(1), 201-208. https://doi.org/10.5539/elt.v4n1p201

Koda, K. (2005). Insights into second language reading: A cross-linguistic approach. New York, NY: Cambridge University Press. https://doi.org/10.1017/CBO9781139524841

Krashen, S. D. (1993). The power of reading: Insights from the research. Englewood, CO: Libraries Unlimited.

Langer, J. (1997). Literacy acquisition through literature. Journal of Adolescent and Adult Literacy, 40(8), 602-614.

Levine, A., Ferenz, O., \& Reves, T. (2000). EFL academic reading and modern technology: How can we turn our students into independent critical readers? TESL-EJ, 4(4).

MacGowan-Gilhooly, A. (1991). Fluency before correctness: A whole-language experiment in college ESL. College ESL, 1(1), 37-47.

Mikulecky, B. S. (2008). Teaching reading in a second language. Pearson Longman.

Obeidat, M. (1997). Language vs. literature in English departments in the Arab world. English Teaching Forum, 35(4).

Zafeiriadou, N. (2004). On literature in the EFL classroom. Retrieved from http//www.Developing Teachers.com

\section{Copyright Disclaimer}

Copyright reserved by the author(s).

This article is an open-access article distributed under the terms and conditions of the Creative Commons Attribution license (http://creativecommons.org/licenses/by/3.0/). 